\title{
The Influence of the Education Provided to Family Caregivers on Bedridden Patients and Caregivers: A Randomized Controlled Study
}

Evde Sağlık Hizmeti Alan Bağımlı Hastalara Bakım Veren Aile Üyelerine Verilen Eğitimin Hastalara ve Bakım Verenlere Etkisi: Randomize Kontrollü Bir Çalışma Züleyha Öğ̈̈̈r ${ }^{* 1}$ Sebahat Gözüm ${ }^{2}$, Erdoğan Taşs ${ }^{3}$, Nurcan Yalçındağ ${ }^{3}$, Mehtap Alpak ${ }^{4}$, Osman Hayran $^{5}$

\section{ABSTRACT}

Objective: This study was conducted with the aim of investigating the influence of the education provided to the caregivers of bedridden patients in accordance with the Ausubel's expository teaching strategy on the patients and the caregivers. Material and Methods: The randomized controlled intervention study included 132 patients (66 males and 66 females) in intervention group and 132 patients in control group and their family caregivers. In the first stage, the healthcare professionals for home care were given en education. In the second stage, 20-hour training intervention was carried out as expository within the frame of requirements determined for family caregivers. The control group was included in the routine program within the scope of home care service. The efficiency of these interventions was evaluated by using knowledge test of bedridden patient care, Zarit burden interview, inventory on evaluation of care provided by family members, pressure sore risk definition form (Braden Scale), and geriatric depression scale (GDS). Results: Intervention and control groups were found to be similar with regard to the parameters measured in pre-test. It was determined that after the training intervention, the caregivers had an increased knowledge level of bedridden patient care $(\mathrm{p}<0,001)$, their care burden significantly decreased $(\mathrm{p}<0.001)$, the efficiency of care provided by the family members was significant in favor of the interventiongroup ( $<<0.05$ ), risk level of pressure sores of the patients was lower in the intervention group compared to control group $(\mathrm{p}<0.05)$, the median value of geriatric depression in bedridden patients decreased from 18 to 15 in intervention group, and their depression symptoms decreased $(\mathrm{p}<0.05)$.Conclusion: The education given as expository to family caregivers of bedridden patients was effective in increasing the caregiving competence, reducing the care burden, increasing the caregiving knowledge level, reducing the pressure risk and decreasing depression level of the patients.

Key words: Education of caregivers, bedridden patient, family caregiver, care burden, caregiving knowledge, caregiving competence, depression, pressure sore risk

\section{ÖZET}

Amaç: $\mathrm{Bu}$ çalışma yatağa bağımlı hastaların bakım vericilerine "Ausubel'in sunuş yoluyla öğretim stratejisi" doğrultusunda yapılan eğitimin etkisini değerlendirmek amacıyla yapılmıştır. Gereç ve Yöntem: Randomize kontrollü müdahale çalışması deseninde yürütülen çalışmada, 66'sı erkek 66'sı kadın olacak şekilde 132 hasta müdahale grubuna, 132 hasta da kontrol grubuna seçilerek, her iki gruptaki hastalar ve bakım veren aile bireyleri çalışma kapsamına alınmıştır. İlk aşamada evde sağlık profesyonellerine eğitim verilmiş, ikinci aşamada aile bakım vericilerine yönelik belirlenen gereksinimler çerçevesinde 20 saatlik eğitim müdahalesi sunuş yolu ile yapılmıştır. Kontrol grubu evde sağlık hizmeti kapsamında rutin programa dâhil edilmiştir. Yapılan girişimlerin etkinliği yatağa bağımlı hasta bakımı bilgi testi, Zarit bakıcı yükü ölçeği, aile üyeleri tarafından verilen bakımı değerlendirme envanteri, bası yaraları risk tanılama formu (Braden ölçeği), geriatrik depresyon ölçeği (GDÖ) ile değerlendirilmiştir. Bulgular: Ölçülen tüm parametreler açısından ön testlerde çalışma ve kontrol grubu arasında fark olmayıp gruplar benzer bulunmuștur. Yapılan eğitim müdahalesi sonrası bakım verenlerdeyatağa bağımlı hasta bakımı bilgi düzeyinin arttığı $(\mathrm{p}<0,001)$,bakım verme yükünün anlamlı olarak azaldığı $(\mathrm{p}<0,001)$, aile üyeleri tarafindan verilen bakımın yeterliliğinin müdahale grubu lehine anlamlı olduğu( $\mathrm{p}<0.05)$, bakım alan hastaların bası yarası risk düzeyinde kontrol grubuna göre müdahale gurubunda daha düşük olduğu( $(p<0.05)$, müdahale gurubunda yer alan yatağa bağımlı hastalarda geriatrik depresyon ortanca değerinin 18 'den 15 'e düştüğü ve depresyon belirtilerinin azaldığ 1 belirlenmiştir $(\mathrm{p}<0.05)$. Sonuç: Yatağa bağımlı hastaların aile bakım vericilerine sunuş yoluyla yapılan eğitim bakım verme yeterliliğini artırmada, bakıcı yükünün azaltılmasında, bakım verme bilgi düzeyini arttırmada, bası riskini azaltmada ve bakım alanların depresyon düzeyini düşürmede etkilidir.

Anahtar kelimeler: Bakım verenlerin eğitimi, yatağa bağımlı hasta, bakım veren aile bireyi, bakım yükü, bakım verme bilgisi, bakım verme yeterliliği, depresyon, bası yarası riski

Received Date / Geliş tarihi: 19.07.2018, Accepted Date / Kabul tarihi: 30.05.2019

${ }^{1}$ T.C. Sağlık Bakanlığı, Antalya İl Sağlık Müdürlüğü, Antalya-TÜRKIYYE.

${ }^{2}$ Akdeniz Üniversitesi Hemşirelik Fakültesi, Antalya-TÜRKIYYE.

${ }^{3}$ T.C. Sağlık Bakanlığı, Antalya Atatürk Devlet Hastanesi, Antalya-TÜRKIYE.

${ }^{4}$ Sağlık Bilimleri Üniversitesi, Antalya Eğitim ve Araştırma Hastanesi, Antalya-TÜRKIYYE.

${ }^{5}$ Medipol Üniversitesi TÜRKIYE.

*Address for Correspondence / Yazışma Adresi: Züleyha Ögür. Antalya İl Sağlık Müdürlüğü, Antalya-TÜRKIYE., E-mail: zuleyha.ogur@ hotmail.com

Öğür Z, Gözüm S, Taş E, Yalçındağ N, Alpak M, Hayran O. Evde Sağlık Hizmeti Alan Bağımlı Hastalara Bakım Veren Aile

Üyelerine Verilen Eğitimin Hastalara ve Bakım Verenlere Etkisi: Randomize Kontrollü Bir Çalışma. TJFMPC, 2019; 13(3):318-334

DOI: $10.21763 /$ tjfmpc.446108 


\section{GíRiş}

Türkiye'nin yaşlı nüfus oranının 2023 yılında $\% 10,2$ 'ye, 2075 yılında \%27,7 yükselerek yaşlı nüfus yapısına sahip ülkeler arasında yer alacağ 1 tahmin edilmektedir. ${ }^{1}$ Yaşlanmakta olan nüfus ve değişmekte olan yaşam şekillerinin bir sonucu olarak da Türkiye'de kronik hastalıklı birey sayısı artmaktadır. Kronik hastalıklı ve engelli bireylerle birlikte günümüzde 30 milyonu aşan bu grubun nüfus projeksiyonları incelendiğinde daha da artacağ öngörülmektedir. ${ }^{2} \quad$ Türkiye'de nüfus hareketliliğindeki değişimler nedeniyle kentleşme oranının artması, hizmet taleplerindeki değişiklikler, ,hastanede kalış sürelerinin kısalması, aile yapılarının ve yaşam şekillerinin değişmesi, kadınların giderek daha fazla çalışma yaşamına girmesi gibi faktörler, günümüzde ve gelecekte yaşlı ve bağımlı bireylerin evde bakım ve sağlık hizmetlerine olan ihtiyacının kaçınılmaz olarak artacağını göstermektedir.

Sağlık ve sosyal bakım ihtiyaçlarının karşılanmasında evde sağlık hizmetleri en etkin model olarak tanımlanmaktadır. ${ }^{2}$ Evde sağlık hizmetleri kurumsal olarak ne kadar iyi verilirse verilsin bakımın en önemli yükünün aile bireylerinde olduğu bilinmektedir. Kurumsal bakım maliyetlerinin ve evde bakım alan hastaların hastanelere geri dönüşlerinin azaltılması, iyileşme süresinde pozitif psikolojik etki sağlanması, iyileşme döneminin kesintisiz olması ve tüm bunların yanı sıra hasta ve yakınlarının uzun süreli bakım sürecinin yıpratıcı etkisinden korunması için evde sağlık hizmetlerinin etkili bir şeklide yürütülmesi ve aile bireylerinin bakım konusunda yeterli hale getirilmesi önemlidir. ${ }^{3}$

Evde sağlık hizmetleri; akut, kronik veya kalıcı yetersizliği olan kişi ve ailesine kendi ortamlarında; bağımsızlıklarını en üst düzeyde tutan, hastalık ve yetersizlikleri en aza indiren, sağlığ1 koruyan, sürdüren ve rehabilite eden, hasta ve ailesinin gereksinimlerine göre planlanan bir hizmet biçimidir. ${ }^{4}$ Evde sağlık hizmetleri ile hastanın yaşam koşulları değiştirilmeden uygulanan tedavi ve bakım süreci ile yaşam kalitesinin ve bağımsızlık düzeyinin olabildiğince arttırılması, hastanede uzun süre kalma sonucu ortaya çıkabilecek hasta ve aileye ait fiziksel, psikolojik, sosyal ve ekonomik sorunların azaltılması gibi faydalar hedeflenmektedir.

Türkiye'de özel sektör öncülüğü ile başlatılan "Evde Sağlık Hizmetleri" 2010 yılından beri Sağlık Bakanlığı ve yerel yönetimler tarafından verilmektedir. "Sağlık Bakanlığg'nca Sunulan Evde Sağlık Hizmetlerinin Uygulama Usul ve Esaslar1 Hakkında Yönerge" kapsamında evde sağlık hizmetlerinden faydalanabilecek hastalar; nörolojik ve kas hastalığı olanlar (Multipl Skleroz [MS],Amyotrofil Lateral Skleroz [ALS],Serebro-vasküler Hastalık [SVH],Demans, Alzheimer, Serebral Palsi), Kronik Obstrüktif Akciğer Hastalığı [KOAH] gibi ileri derece solunum sistemi hastalığına sahip bireyler, terminal dönem kanser hastaları, ağır engeli bulunan hastalar, morbid obezite vb sebeplerle yatağa bağımlı olan hastalara hizmet götürülmektedir. Verilen hizmetin kapsamı ise tanısı konulmuş evde sağlık hastasının ev ortaminda planlanan tedavisinin yapilmasi, muayene, tetkik, , tıbbi bakım ve rehabilitasyon hizmetinin verilmesi, ilgili dal uzmanlarından konsültasyon sağlanması, ağız ve diş sağlı̆̆1 hizmetinin ev ortamında sağlanması, tıbbi cihaz, ilaç kullanım raporu ve malzeme teminine yönelik raporların çıkarılmasına yardımcı olunması, evde kullanılan tıbbi ekipmanın doğru ve uygun koşullarda kullanılmasına yönelik danışmanlık sağlanması, hastanın ve ailesinin bakım süreçleri ile ilgili bilgilendirilmesini kapsamaktadır. ${ }^{5}$

Sağlık Bakanlığı'nın yıllara göre evde sağlık hizmet verileri incelendiğinde ulaşılan toplam hasta say1s1 2010 y1lında 16.651 iken, 2015 yılında 639.359 kişiye ulaşmıştır. Aktif kayıtlı hasta sayıs1 2010 yılında 16.651 iken 2015 yılında 257.484 kişiye ulaşmıştır. Birim sayısı 2010 y1lında 407 iken 2015 y1lında 946'ya ulaşmıştır. ${ }^{6}$ Antalya ili evde sağlık verileri incelendiğinde ise aktif kayıtlı hasta sayısı 2014 yılında 4263 iken 2017 yılında 6437 kişiye ulaşmıştır. Ulaşılan toplam hasta sayısı 2014 yılında 8146 iken, 2017 yılında 15746 olmuştur. Antalya'da tüm evde sağlık birimleri 2014- 2017 yılları arasında 46525 kişiye ulaşmıştır. ${ }^{7} \mathrm{Bu}$ veriler evde sağlık hizmetlerinin giderek artan önemini vurgular niteliktedir.

Evde sağlık hizmetlerinde ekip ve personel sayısında artış sağlamak için çalışılsa da artan hasta sayısına oranla yetersiz kaldığ gözlenmektedir. Evde sağlı ekipleri plan doğrultusunda hizmet verdiği evlerde 15-20 dakika içinde hizmeti sunup bir diğer hasta için evden ayrılmak durumundadır. Sağlık ekibi bu kısıtlı süre içinde bireyin ihtiyacı olan sağlık hizmeti dışında hasta ve yakınlarına eğitim ve danışmanlık gibi hizmetleri de sunmaktadır. Hastasının bakımını 7 gün 24 saat sağlayan aile bireyleri için sağlık bakım ekibi tarafından verilen eğitim ve danışmanlıklar ailenin bakım yeterliliğini ve bunun yansıması olarak hastanın 
bakım kalitesini doğrudan etkileyecektir. Dolayısı ile bakım verenlerin hasta bakımı konusunda alanında uzmanlar tarafından sürekli olarak bilgilendirilmesi ve öğrenim materyallerinin sağlanması önemlidir.

Ülkemizdeki kültürel değerler ve verilen sağlık hizmetlerinin yapısı, aile bakımının; hasta, ailesi ve sağlık bakım maliyetinin azalması açısından pek çok faydası bulunmaktadır. Bireylere kendi yakınları tarafından bakım verilmesi fiziksel ve psikolojik olarak hastaların iyilik halini olumlu etkilemesine rağmen yapılan çalışmalar bakım verenlerin ve bakım alanların bazı sorunlarla karşılaştıklarını, bakım vermeye ilişskin bilgi eksiklikleri nedeniyle uzman yardımına gereksinim duyduklarını göstermektedir. Bakım vermeye ilişkin bilgi eksiklikleri hem bakım verenlerin hem de bakım alanların olumsuz etkilenmesine neden

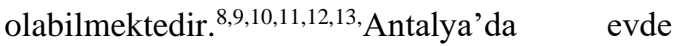
sağlık hizmetleri çalışanların gözlemlerine göre; yatağa bağımlı hastaların bakım vereninin bakımla ilgili bilgi yetersizliğinden kaynaklanan sağlık sorunları (komplikasyonları) bulunmaktadır. Bunlar; hareketsizliğe bağlı kontraktür ve dekübit yaraları, idrar yolu enfeksiyonları, akciğer enfeksiyonları, etkisiz solunum, tedaviye katılma/sürdürme güçlüğü, beslenme bozukluğu vb. olarak siralanmaktadır. Bu sorunlar yeterli ve doğru bakımla önlenebilecek problemlerdir.

Bakımdan sorumlu aile bireylerinin eğitim ve psikososyal destekten yoksun olarak hizmet vermeye çalışmaları halinde ciddi bir hastalık yükü ile karşı karşıya kaldıkları, özellikle depresyon sorununu yaygın biçimde yaşadıkları bildirilmiştir. ${ }^{14,15}$ Bakım vericilerin yaşadığ zorluk ve yük sıklıkla fark edilmez ve kontrolsüz bırakılırsa bakım vericiler için kötü sağlık sonuçlarına neden olabilir. Aile bakım vericileri evde hastasına bakım verirken fiziksel, psikolojik ve ekonomik olarak önemli yükler üstlenirler. Var olan diğer sorumlulukların tümü üst üste geldiğinde sıklıkla kendilerini fiziksel ve psikolojik açıdan tükenmiş olarak tanımlar ve yardım konusunda daha fazla bilgiye ihtiyaç duyabilirler. Evde bakımda sadece hastayı değil aynı zamanda bakım veren ve diğer aile bireylerini de düşünmek gerekir. Evde bakımı kendi sınırlı olanakları ile sağlamaya çalıșan aileler için ciddi ekonomik yüke neden olabilir. Bu durum tüm aileyi olumsuz etkileyebilir. ${ }^{16}$

$\mathrm{Bu}$ çalışma,TÜBİTAK 3001 programı ve 213S075 no'lu proje desteği ile ülkemizde evde sağlık hizmetlerinin gelişimine katkıda bulunmak, yatağa bağımlı hastaların bakım vericilerine sunuş yoluyla öğretim stratejisi kullanılarak uygulanan eğitimin, kontrol grubuna kıyasla, müdahale grubunda yatağa bağımlı hastalar ve bakım verenler açısından ne gibi farklılıklara yol açtığını göstermek amacıyla yapılmıştır.

\section{GEREÇ VE YÖNTEM}

\section{Araştırmanın Şekli}

Çalışma yatağa bağımlı hastaların bakım vericilerine sunuş öğretim stratejisi kullanılarak uygulanan eğitim programının, "evde sağlık hizmeti alan yatağa bağımlı kişilerin bakım veren aile üyelerine, bakıma ilişkin verilen eğitimin, hasta ve bakım veren açısından değerlendirilmesi" amacı ile randomize kontrolü müdahale çalışması şeklinde yapılmıştır. Çalışma CONSORT kullanılarak tasarlanmıştır. Yöntem, katılımcıların seçimi, örneklem seçimi, randomizasyon yöntemi, çalışma dizaynı, yöntemler, bulgular ve sonuçlar dahil tüm uygunluk kriterleri açısından CONSORT web sayfası ve ilgili yayınlar incelenerek çalışma tasarlanmıştır. ${ }^{17-18}$

\section{Araştırmanın Yapıldığı Yer ve Zaman}

Araştırma, Antalya il merkezinde Atatürk Devlet Hastanesi ile Eğitim ve Araştırma Hastanesi'nin evde sağlık birimlerinden sağlık bakım hizmeti almakta olan yatağa bağıml hastalar ve bakım verenleri üzerinde 2014 Kasım ve 2015 Haziran ayları arasında yapılmıştır.

\section{Araştırmanın Evreni ve Örneklemi}

Antalya Eğitim ve Araştırma Hastanesi ile Atatürk Devlet Hastanesi'nden hizmet almakta olan yatağa bağımlı hastalar ve bunlara bakım veren yakınları araştırma evrenini oluşturmuştur. 2015 y1l itibariyle bu hastanelerden hizmet almakta olan hasta sayis1 1081'dir. G*power programı kullanarak 0,95 güçle örneklem sayısı birinci ve ikinci grup için 88 olmak üzere toplam 176 bulunmuş olup, ölüm gibi nedenler ile örneklem kaybı riski ve çalışmayı güçlendirmek amacıyla örneklem sayısı fazla alınmıştır. Bin seksen bir yatağa bağımlı hasta arasından 66'sı erkek, 66'sı kadın olacak şekilde 132 hasta müdahale grubuna, 132 hasta da kontrol grubuna rastgele yöntemle seçilerek, her iki gruptaki hastalara bakım veren aile bireyleri belirlenmiştir. Seçim yapılırken hastalar kadın ve erkek olarak ayrı ayrı listeler olarak birden başlayarak 
numaralandırılmıştır. Birden başlayarak hasta sayısı kadar ardışık sayı yazılıp, kase içerisine konulmuştur. Evde sağlık ekibi ile herkes birer numara çekmek suretiyle belirlenen örneklem sayısı kadar çekiliş yapılmış, çıkan numaralar başlangıçta oluşturulan listelerden ayrılarak yeniden kadın ve erkek olarak listelenmiştir. İkinci aşamada aynı işlem kontrol ve müdahale grubunun seçimi için yapılmıştır.

Çalışmaya alınan hastalar ve bakım veren yakınları için araştırmaya kabul kriterleri şu şekilde belirlenmiştir;

- Bakım verilen bireyin Barthel İndeksi'ne göre en az beş alanda bağımlı olması,

- Çalışmanın girişim süresi (üç ay) boyunca ailesi tarafından ve sürekli aynı evde bakılması,

- $\quad$ Bakım vericinin 18 yaş ve üzerinde olmas1,

- Bakım vericinin soruları anlayabilecek düzeyde olması,

- Bakım veren bireyin yatağa bağıml hastanın bakımından doğrudan sorumlu olmas1.

Evin uzak olması, dil problemleri, eğitime devam etmemesi ve hastanın kaybedilmesi dışlama kriterleri olarak alınmıştır.

\section{Veri Toplamada Kullanılan Formlar}

Hasta yakını (22 soru) ve hastaya ilişkin tanımlayıcı soru formunda (7 soru) bakım veren ve alan bireyi tanıtıcı bilgiler yer almaktadır.

\section{Bakım vereni değerlendirme araçları;}

Yatağa Tam Bağımlı Hasta Bakımı Bilgi Düzeyi Değerlendirme Testi: Eğitim programı öncesi ve sonrası bakım veren aile üyelerinin yatağa bağımlı hasta bakımıla ilgili bilgi düzeylerini değerlendirmeye yönelik Cingil tarafından doktora tezi için oluşturulan ve 33 sorudan oluşan bilgi değerlendirme testi izin alınarak uyarlanmıştır. ${ }^{19}$ Bilgi testi bakım verme bilgisini sorgulayan çoktan seçmeli sorulardan oluşmaktadır. Her bir doğru cevap yaklaşık 3.3 puan olarak hesaplanmakta, yaşlı bakımı bilgi düzeyi testi puanı 100 üzerinden değerlendirilmektedir. Testten alınan puanın artması bakım verenin yaşlı bakımı bilgi düzeyinin iyi olduğunu göstermektedir. ${ }^{20}$
Zarit Bakıcı Yükü Ölçeği: Zarit, Reever ve Bach-Peterson tarafindan 1980 yılında geliştirilmiştir. Bakım gereksinimi olan bireye bakım verenlerin yaşadığı sıkıntıyı değerlendiren ve 22 maddeden oluşan bir ölçektir. Ölçek," asla", "nadiren”, "bazen”, “sık s1k" ya da "hemen her zaman" şeklinde 0'dan 4'e kadar değişen Likert tipi değerlendirmeye sahiptir. Ölçeğin Türkçe uyarlaması İnci tarafından yapılmıştır ve iç tutarlılığının .95 bulunduğu ve güvenilir bir araç olduğu belirlenmiştir. $^{21}$

Aile Üyeleri Tarafindan Verilen Bakımı Değerlendirme Envanteri: Aile bakım verme kapasitesini değerlendirmede sağlık profesyonellerine yardım etmesi amaciyla 2000 yılında Chang Gung Üniversitesi'nden Prof.Dr. Yea-Ing Lotus Shyu tarafından geliştirilip 2008 yılında Cingil ve Gözüm tarafından Türkçeye uyarlanıp, geçerlilik ve güvenirliği yapıllmıştır. $^{22}$ Sağlık profesyonellerinin bakım vericilerinin gözleme dayalı olarak değerlendirdiği bir envanterdir. Envanterdeki ifadeler aile bakım verme etkenlerini 4 alt bölümde toplar.

Bakım Verenin Bakım Alanla İlgili Bilgi Düzeyi: Bu bölüm bakım verenin bakım alan için yaptığ 1 ve bakım verme eylemlerini etkileyebilen durumları anlama düzeyini ölçmektedir. Bu alt boyuttan alınan düşük puan, bakım verenin yaşlıyla ilgili bilgi düzeyinin düşük olduğunu gösterir ve alt boyutun minimum ve maksimum puan değerleri 735 'tir.

Bakım Vermede Yaşanan Güçlükler: $\mathrm{Bu}$ bölüm bakım verenin bakım alan için yapması gerekenler hakkında hissettiği zorlukların derecesini ölçmektedir. Bu alt boyuttan alınan yüksek puan bakım verenin bakım vermede zorlandığı anlamına gelir ve alt boyutun minimum ve maksimum puan değerleri 630'dur.

Bakım Verme Kaynakları: $\mathrm{Bu}$ alt boyuttan düşük puan alınması bakım verme kaynaklarının yeterli olmadığı anlamına gelir ve alt boyutun minimum ve maksimum puan değerleri 7-21'dir.

Bakım Verenin Kendisinden Beklentileri: $\mathrm{Bu}$ bölüm bakım verenin bakım verme rolünü yerine getirirken öz-beklentilerini gerçekleştirme düzeyini ölçmektedir. $\mathrm{Bu}$ alt boyuttan düşük puan alınması bakım verenin bakım verme yeterliliğine ilişkin kendisinden beklentisinin düşük düzeyde olduğu anlamına 
gelir ve alt boyutun minimum ve maksimum puan değerleri 5-15' dir. ${ }^{22}$

\section{Hasta sonuçlarını değerlendirme araçları}

Braden Basınç Ülseri Risk Değerlendirme Ölçeği: Bu formla basınç ülseri risk tanılaması ön-test ve son-testte evde sağlık çalışanları tarafından yapılmıştır. Braden Basınç Ülseri Risk Değerlendirme Ölçeği (B-BÜRDÖ)'nin Türkçe formunun geçerlik ve güvenirlik çalışması iki kez yapılmış olup bilimsel çalışmalarda ve uygulamada sıklıkla kullanılmaktadır. ${ }^{23,24}$

Geriatrik Depresyon Ölçeği (GDÖ): Yesavage ve ark. tarafindan 1983 yılında geriatrik popülasyondaki depresyon hastalarında depresyon varlığını araştırmak amacıyla geliştirilmiştir. GDÖ 30 maddeden oluşmaktadır. Her maddeyi hasta "Evet" veya "Hayır" şeklinde işaretlemektedir. Otuz maddenin 10'u olumsuz, 20'si ise olumlu olarak kurgulanmıştır. Ölçeğin kesme noktası 13/14 olarak kabul edilmektedir. "Geçtiğimiz hafta" şeklinde bir zaman periyodunu sorgulamaktadır. Ölçeğin Türkçe geçerlik ve güvenirlik çalışması 1997 yılında Ertan ve arkadaşları tarafindan yapılmıştır. ${ }^{25,26,27}$

\section{5-Verilerin Toplanması ve Girişim Uygulama Basamakları}

1)-Araştırmanın ilk aşamasında 30 saatlik eğitici eğitimi yapılmıştır. "Evde Sağlık Hizmetleri Eğitici Eğitimi"11-15.08.2014 tarihleri arasında Akdeniz Üniversitesi Hemşirelik ve Eğitim Fakültesi öğretim üyeleri tarafından yapılmıştır. İçerik evde sağlık hizmetleri kapsamında olan hasta ve bakım verenlerin profili ve gereksinimleri, yetişkin eğimi ilkeleri ve projenin tanıtılması ile veri toplama araçlarının doldurulmasından oluşmaktadır. Eğitim öncesi ve sonrası 100 soru ile ön test-son test yapılmıştır. Evde sağlık personelinin doğru cevap oran ortalaması \%50'den \%90'a yükselmiştir.

2)-Örneklem Antalya Atatürk Devlet Hastanesi ve Eğitim ve Araştırma Hastanesi Evde Sağlık Birimlerinden hizmet alan yatağa bağıml hastalar arasından seçilmiștir. Kontrol ve müdahale grubu belirlendikten sonra, yürütücü ve araştırmacı ve evde sağlık ekipleriyle üçer kişilik ekipler oluşturulmuş ve hem hasta hem de bakım verenler için çok sayıda değerlendirme aracı olduğu için ön test verileri hastaların evine gidilerek ikişer ziyaret ile toplanmıştır.
3)-Bas1 yarası risk değerlendirme ve bakım verme yeterliliği gözleme dayalı ölçümler olduğu için örnekleme alınan 10 hasta bakım verende ön-testler yapılmış ve gözlemciler arasında fark olup olmadığı çapraz değerlendirme ile bakılmıştır. Farklılıklar değerlendirilip araştırmacılar ile bir toplantıda nedenleri ortaya konularak çözümlenmiştir.

4)-Kontrol ve müdahale grubunun ön-testleri alındıktan sonra müdahale grubuna eğitim müdahalesi yapılmıştır. müdahale grubuna Antalya Atatürk Devlet Hastanesi ve Eğitim ve Araştırma Hastanesi konferans salonlarında 20 saatlik eğitim, 23-27 Şubat 2015 tarihlerinde sunuş yöntemi ile yapılmıştır. "Evde Sağlık Hizmetleri Eğitici Eğitimi Sertifika Programı" katılan 21 evde sağlık hizmetleri personeli (doktor, hemşire, psikolog, sosyal hizmet uzmanı) önceden hazırlanan eğitim modülünü (fizik tedavi rehabilitasyon, iletişim, güvenli çevre gibi 20 konu başlığı) sunmuştur. Eğitimde bakım verenlere Antalya Kamu Hastaneler Birliği tarafından hazırlanmış olan "Evde Bakım Rehberi" dağıtılmıştır. Eğitim müdahalesine devam sağlanabilmesi için Antalya Büyükşehir ve ilçe belediyelerinin evde sağlık birimleri evde bakım ve araç desteği sağlamıştır. Eğitime katılım sağlayan katılımcılar servislerle evlerinden alınıp bırakılmıştır. Eğitim boyunca dört servis hizmet sunmuştur. Antalya tüm evde sağlık birimleri eğitim için komşu veya akraba gibi başka birini bulamayan kişilere bakım için destek sağlamıştır.

5)-Müdahale grubunda tüm çabalarımıza rağmen eğitimlere çeşitli sebeplerle (hastasının kötüleşmesi vb.) devamsızlık yapılmıştır. Biriki kez devamsızlık yapan 17 kişi için ek program yapılmış, devamsızlık yaptığı konular iki ziyarette evde eğitim ile tamamlanmıştır. Eğitime davet edildiği halde hiç katılmayan 9 kişi ise çalışmadan çıkarılmıştır

6)-Son- testler 3 ay sonra her iki gruptan da alınmıştır ( Bkz. Şekil 1).

7)-Proje kapsamında aile bakım vericilerin ihtiyacı olduğu gözlenen konularda bilgilerini arttırmak, eğitimin sürekliliğini sağlamak ve yaygınlaştırma için alanında uzman kişilerin anlatımlarından oluşan 90 eğitim videosu ve yazılı materyalleri kapsayan bir web sayfası (https://antalyaesh.saglik.gov.tr/)

hazırlanmıştır. 


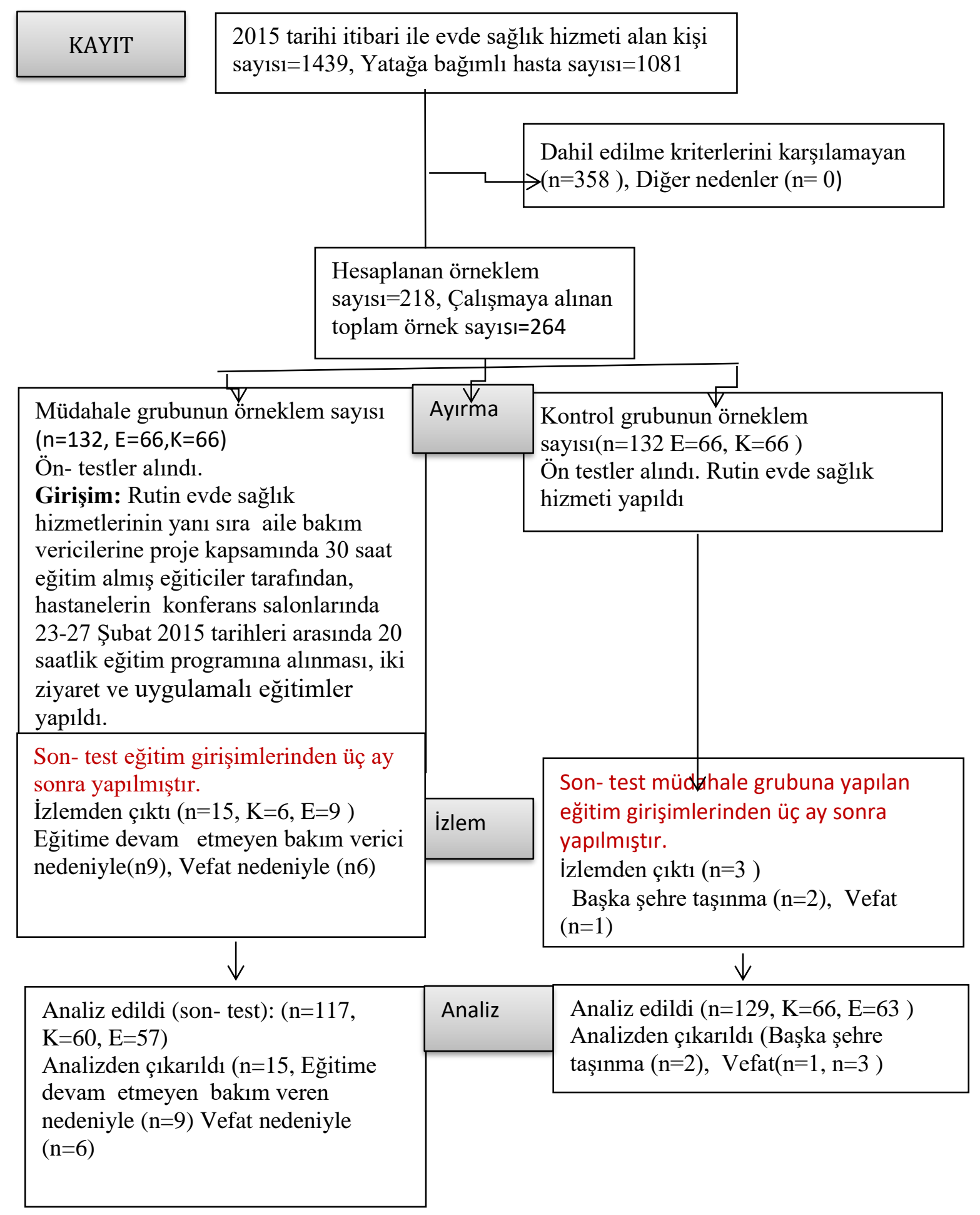

Şekil 1. Consort 2010 akış diyagramına göre araştırma aşamaları

\section{6-Verilerin değerlendirilmesi}


Veriler SPSS 18 programı ile analiz edilmiştir. Verilerin normal dağılıma uyup uymadığına Kolmogorov Smirnov tek örneklem testi ile bakılmıştır. Çalışma ve kontrol grubuna ait kategorik veriler arasındaki benzerliğe ki-kare analizi, grup içi öncesi sonrasi/ değişimi bağımlı iki örnek (paired t) ve Wilcoxon testleriyle gruplar arası eğitim öncesi ve sonrası değişimi belirlemede; normal dağılımlarda $\mathrm{t}$ testi, normal dağılmayan değişkenlerde Mann Whitney $U$ ile analiz edilmiştir. Tanımlayıcı istatistikler olarak kategorik veriler için yüzde, kantitatif veriler medyan (50. persentil) ile 1.-3. Kuartil (25. ve 75. persentil) değerleri kullanılmıştır.

\section{7- Araştırmanın Etik Yönü}

213S075 no'lu proje TÜBİTAK 3001 programına başvuru yapılmadan önce Antalya Eğitim ve Araştırma Hastanesi Etik Kurulu'ndan izin alınmıştır. Ayrıca Antalya Kamu Hastaneleri Birliği, Antalya Eğitim ve Araştırma Hastanesi ile Atatürk Devlet Hastanesi iş birliği ile yürütülmüştür.

\section{BULGULAR}

Tablo 1'de görüldüğü gibi çalışma ve kontrol grubundaki bakım verenler, çocuk sayıları dışında, cinsiyet, yaş, öğrenim, çalışma ve medeni durum, sosyal güvence ve ekonomik durum algisı yönünden benzer dağılım göstermektedir. Tablo 2 ve 3 'de her iki grubun bakım vericilerinin çeşitli özelliklerinin dağılımı karşılaştırmalı olarak sunulmuştur. Görüleceği gibi iki grubun bakım vericileri tüm özellikler açısından birbirine benzer olup, tek farklılık sahip olunan çocuk sayısı konusundadır. Müdahale grubunda çocuğu olmayan bakım verici sayısı kontrol grubuna göre daha fazladır (Tablo 1, $\mathrm{p}=0.043$ ).

Bakım alan yatağa bağımlı hastaların yaş ortancaları arasında fark yoktur $(\mathrm{p}=0,839)$. Kontrol grubunun yaş medyanı 72 , müdahale grubunun yaş medyanı ise 75 olarak belirlenmiştir.
Tablo 4'de müdahale ve kontrol grubundaki hastaların çeşitli özelliklerinin dağılımı karşılaştırmalı olarak verilmiştir. Tabloda da görüldüğü gibi gruplar arasında sosyodemografik değişkenler ve genel sağlık durumu açısından önemli fark olmayıp gruplar benzer bulunmuştur.

Tablo 5'te görüldüğü gibi, müdahale ve kontrol grubundaki hastaların depresyon puanları arasında gerek ön-test sirasında gerekse son-test sirasında önemli farklılık bulunmamıştır. Ancak, gruplar kendi içerisinde değerlendirildiğinde, kontrol grubu bireyleri arasında ön-test ve son-test arasında önemli fark bulunmaz iken, müdahale grubu bireyleri arasındaki ön-test ve son- test depresyon puanları önemli şekilde farklı bulunmuştur $(\mathrm{p}=0.011)$. Müdahale grubunda ön-test sirasında 18 bulunan puan ortanca değeri sontest sırasında $15^{\prime}$ 'e düşmüştür. Tablo 5 'te görüldüğü gibi, müdahale ve kontrol grubundaki hastaların Bası Yarası Risk Tanılama Toplam puanları arasında gerek öntest sırasında gerekse son-test sırasında önemli farklılık bulunmamıştır. Ancak gruplar kendi içerisinde değerlendirildiğinde, kontrol grubu bireyleri arasında ön-test ve son-test arasında önemli fark bulunmaz iken, müdahale grubu bireyleri arasındaki ön-test ve son test bası yarası risk tanılama puanları önemli şekilde farklı bulunmuştur $(p=0.033)$. Müdahale grubunda ön-test sirasında 15 bulunan puan ortanca değeri son test sirasinda 14'e düşmüştür.

Tablo 6'da aile üyeleri tarafindan verilen bakımın envanteri, Zarit bakıcı yükü, bilgi düzeyi değerlendirme testi sonuçları sunulmuştur. Tüm testler açısından müdahale ve kontrol grubunun ön-test değerleri arasında istatistiksel olarak önemli fark olmayıp gruplar benzer bulunmuştur. Son-test sonuçları açısından iki grup arasındaki farklılıklar tüm ölçümler açısından önemli şekilde farklı bulunmuştur. 


\begin{tabular}{|c|c|c|c|c|c|c|c|}
\hline & \multicolumn{2}{|c|}{ Kontrol } & \multicolumn{2}{|c|}{ Çalışma } & \multirow{2}{*}{$\begin{array}{l}\text { Toplam } \\
\text { (n) }\end{array}$} & \multirow[t]{2}{*}{$\%$} & \multirow[t]{2}{*}{$\mathbf{p}^{*}$} \\
\hline & (n) & $\%$ & (n) & $\%$ & & & \\
\hline \multicolumn{8}{|l|}{ Cinsiyet } \\
\hline Kadın & 106 & 82,2 & 90 & 76,9 & 196 & 79,7 & \multirow[t]{3}{*}{,343 } \\
\hline Erkek & 23 & 17,8 & 27 & 23,1 & 50 & 20,3 & \\
\hline Toplam & 129 & 100 & 117 & 100 & 246 & 100 & \\
\hline \multicolumn{7}{|l|}{ Yaş } & \multirow[t]{5}{*}{,347 } \\
\hline $20-39$ & 16 & 12,5 & 9 & 7,7 & 25 & 10,2 & \\
\hline $40-49$ & 32 & 25 & 26 & 22,2 & 58 & 23,7 & \\
\hline 50 ve üzeri & 80 & 62,5 & 82 & 70,1 & 162 & 66,1 & \\
\hline Toplam** & 128 & 100 & 117 & & 245 & 100,0 & \\
\hline \multicolumn{7}{|l|}{ Öğrenim Durumu } & \multirow[t]{7}{*}{ 693 } \\
\hline Okur-yazar değil & 17 & 13,3 & 13 & 11,1 & 30 & 12,2 & \\
\hline Okur-yazar & 8 & 6,3 & 7 & 6,0 & 15 & 6,1 & \\
\hline İlköğretim & 68 & 53,1 & 64 & 54,7 & 132 & 53,9 & \\
\hline Lise & 21 & 16,4 & 25 & 21,4 & 46 & 18,8 & \\
\hline Üniversite & 15 & 10,9 & 8 & 9,0 & 22 & 9 & \\
\hline Toplam** & 128 & 100 & 117 & 100 & 245 & 100 & \\
\hline \multicolumn{7}{|l|}{ Çalışma Durumu } & \multirow{5}{*}{,998 } \\
\hline Çalışıyor & 10 & 7,8 & 9 & 7,7 & 19 & 7,8 & \\
\hline Emekli / Çalışamıyor & 31 & 24,2 & 28 & 23,9 & 54 & 22 & \\
\hline Ev hanımı & 87 & 68,0 & 80 & 68,4 & 167 & 70,2 & \\
\hline Toplam** & 128 & 100 & 117 & 100 & 5 & 100 & \\
\hline \multicolumn{7}{|l|}{ Medeni Durum } & \multirow{5}{*}{, 372} \\
\hline Bekar & 7 & 5,5 & 11 & 9,4 & 18 & 7,3 & \\
\hline Evli & 107 & 83,6 & 97 & 82,9 & 204 & 83,3 & \\
\hline Boşanmış & 14 & 10,9 & 9 & 7,7 & 23 & 9,4 & \\
\hline Toplam** & 128 & 100 & 117 & 100 & 245 & 100 & \\
\hline \multicolumn{7}{|l|}{ Çocuk Sayısı } & \multirow{6}{*}{,043 } \\
\hline 0 & 6 & 4,7 & 14 & 12 & 20 & 8,2 & \\
\hline 1 & 21 & 16,4 & 11 & 9,4 & 32 & 13,1 & \\
\hline 2 & 42 & 32,8 & 47 & 40,2 & 89 & 36,3 & \\
\hline 3 ve üzeri & 59 & 46,1 & 45 & 38,5 & 104 & 42,4 & \\
\hline Toplam** & 128 & 100 & 117 & 100 & 245 & 100 & \\
\hline \multicolumn{7}{|l|}{ Sosyal Güvence } & \multirow{4}{*}{0,82} \\
\hline Var & 117 & 91,4 & 106 & 90,6 & 245 & 91 & \\
\hline Yok & 11 & 8,6 & 11 & 9,4 & 22 & 9 & \\
\hline Toplam** & 128 & 100 & 117 & & 245 & 100 & \\
\hline \multicolumn{7}{|c|}{ Size göre ailenizin ekonomik durumu nasıldır? } & \multirow{4}{*}{,401 } \\
\hline Gelir giderden düşük & 81 & 63,3 & 80 & 68,4 & 161 & 65,7 & \\
\hline Gelir gidere denk veya fazla* & 47 & 36,7 & 37 & 31,6 & 84 & 34,3 & \\
\hline Toplam** & 128 & 100 & 117 & 100 & 245 & 100 & \\
\hline
\end{tabular}

*Geliri giderinden fazla 1 kişi olduğundan birleştirilmiştir. ** Bir kayıp veri * ki-kare analizi, 


\begin{tabular}{|c|c|c|c|c|c|c|c|}
\hline & \multicolumn{2}{|c|}{ Kontrol } & \multicolumn{2}{|c|}{ Çalışma } & \multirow{2}{*}{ Toplam (n) } & \multirow{2}{*}{$\%$} & \multirow{2}{*}{$\mathbf{p}^{*}$} \\
\hline & $\mathbf{n}$ & $\%$ & $\mathbf{n}$ & $\%$ & & & \\
\hline \multicolumn{7}{|c|}{ Hastaya yakınlık derecesi? } & \multirow{5}{*}{, 126} \\
\hline Eşi & 49 & 38,3 & 38 & 32,5 & 87 & 35,5 & \\
\hline Çocuğu & 43 & 33,6 & 54 & 46,2 & 97 & 39,6 & \\
\hline Diğer & 36 & 28,1 & 25 & 21,4 & 61 & 24,9 & \\
\hline Toplam*** & 128 & 100 & 117 & 100 & 245 & 100 & \\
\hline \multicolumn{7}{|c|}{ Daha önce bir yakınınıza bakım verdiniz mi? } & \multirow{4}{*}{,609 } \\
\hline Evet & 24 & 18,8 & 25 & 21,4 & 49 & 20 & \\
\hline Hayır & 104 & 81,3 & 92 & 78,6 & 196 & 80 & \\
\hline Toplam*** & 128 & 100 & 117 & 100 & 245 & 100 & \\
\hline \multicolumn{7}{|c|}{ Bağımlı hastanın sizinle birlikte yaşama durumu nedir? } & \multirow{4}{*}{, 351} \\
\hline Sürekli & 121 & 94,5 & 106 & 90,6 & 227 & 92,7 & \\
\hline Geçici & 7 & 5,5 & 11 & 9,4 & 18 & 7,3 & \\
\hline Toplam** & 128 & 100 & 117 & 100 & 245 & 100 & \\
\hline \multicolumn{7}{|c|}{ Hastanıza ait ayrı bir oda var mı? } & \multirow{4}{*}{,403 } \\
\hline Evet & 80 & 65,5 & 67 & 57,3 & 147 & 60 & \\
\hline Hayır & 48 & 37,5 & 50 & 42,7 & 98 & 40 & \\
\hline Toplam** & 128 & 100 & 117 & 100 & 245 & 100 & \\
\hline \multicolumn{7}{|c|}{ Hastanıza bakarken size yardımcı olan başka birisi var mı? } & \multirow{4}{*}{,534 } \\
\hline Evet & 76 & 59,4 & 74 & 63,2 & 150 & 61,2 & \\
\hline Hayır & 52 & 40,6 & 43 & 36,8 & 95 & 38,8 & \\
\hline Toplam** & 128 & 100 & 117 & 100 & 245 & 100 & \\
\hline \multicolumn{7}{|c|}{ Seçme şansınız olsaydı yaşlı veya yatağa bağımlı birine bakmak ister miydiniz? } & \multirow{4}{*}{,637 } \\
\hline Evet & 38 & 29,7 & 38 & 32,5 & 76 & 31 & \\
\hline Hayır & 90 & 70,3 & 79 & 67,5 & 169 & 69 & \\
\hline Toplam*** & 128 & 100 & 117 & 100 & 245 & 100 & \\
\hline \multicolumn{7}{|c|}{ Dışarıya çıkmanız gerektiğinde sizin yerinizi alacak birisi var mı? } & \multirow{4}{*}{, 515} \\
\hline Evet & 87 & 68 & 84 & 71,8 & 171 & 69,8 & \\
\hline Hayır & 41 & 32 & 33 & 28,2 & 74 & 30,2 & \\
\hline Toplam** & 128 & 100 & 117 & 100 & 245 & 100 & \\
\hline
\end{tabular}

** Bir kayıp veri (Bir bakım veren son- test sırasında, ön- testte alınan tanımlayıcı verileri kullanmamızı istemediğini diğer kısımları araştırmaya dahil edebileceğimizi ifade etmesi nedeniyle oluşmuştur).* ki-kare analizi, 


\begin{tabular}{|c|c|c|c|c|c|}
\hline \multicolumn{6}{|c|}{ Tablo 3.Bakım verenleri tanıtıcı bilgiler } \\
\hline & \multirow{2}{*}{ Grubu } & \multicolumn{2}{|c|}{ Persentil } & \multirow{2}{*}{ (n) } & \multirow{2}{*}{$\mathbf{p}^{*}$} \\
\hline & & 50 & $25-75$ & & \\
\hline \multirow{2}{*}{ Evde kaç kişi yaşıyorsunuz? } & Kontrol & 3 & $2-5$ & 128 & \multirow{2}{*}{,717 } \\
\hline & Çalışma & 3 & $2-4$ & 117 & \\
\hline \multirow{2}{*}{$\begin{array}{l}\text { Hastanıza sizden başkası en fazla } \\
\text { kaç saat bakabilir? }\end{array}$} & Kontrol & 3 & $2-6$ & 124 & \multirow{2}{*}{,485 } \\
\hline & Çalışma & 3 & $1-8$ & 111 & \\
\hline \multirow{2}{*}{$\begin{array}{l}\text { Hastaya kaç gündür siz } \\
\text { bakıyorsunuz? }\end{array}$} & Kontrol & 1440 & $720-3600$ & 128 & \multirow{2}{*}{,911 } \\
\hline & Çalışma & 1440 & $720-2880$ & 117 & \\
\hline \multirow{2}{*}{$\begin{array}{l}\text { Hastanıza bakım vermek için } \\
\text { günde ortalama kaç saatinizi } \\
\text { ayırıorsunuz? }\end{array}$} & Kontrol & 24 & $18-24$ & 128 & \multirow{2}{*}{, 512} \\
\hline & Çalışma & 24 & $10-24$ & 117 & \\
\hline \multirow{2}{*}{$\begin{array}{l}\text { Hastanıza daha önceki ilişkinizin } \\
\text { "duygusal bağlılık" düzeyini nasıl } \\
\text { tanımlarsınız? (VAS)* }\end{array}$} & Kontrol & 10 & $9-10$ & 128 & \multirow{2}{*}{, 851} \\
\hline & Çalışma & 10 & $9-10$ & 117 & \\
\hline \multirow{2}{*}{$\begin{array}{l}\text { Hastanıza şimdiki ilişkinizin } \\
\text { "duygusal bağlılık" düzeyini nasıl } \\
\text { tanımlarsınız(VAS*) }\end{array}$} & Kontrol & 10 & $9,25-10$ & 128 & \multirow{2}{*}{,431 } \\
\hline & Çalışma & 10 & $9-10$ & 117 & \\
\hline
\end{tabular}

VAS*: Visual Analog Skala, duygusal bağımlılık düzeyi 0: duygusal bağlılık yok, 10: çok güçlü duygusal bağlılık,* ki-kare analizi

\section{TARTIŞMA}

$\mathrm{Bu}$ çalışma evde sağlık personelinin eğitimi, bakım veren aile bireylerinin eğitimi ve bunun bakım veren ve hasta sonuçlarına etkisini değerlendirmek amaciyla yapılan bir araştırma projesinin sonuçlarını raporlamaktadır. $\mathrm{Bu}$ proje gibi evde sağlık alanında personel eğitimi yapılarak sertifikalandıran, hem araştırma kapsamında bakım verenlere standart eğitim veren, verilen eğitimlerin etkisini hem bakım veren hem bakım alan açısından ölçen, hem de açık eğitim kaynakları oluşturan başka bir çalışma bulunamamıştır.

$\mathrm{Bu}$ çalışmaya göre, bakım verici rolünün çoğunluğunu ilköğretim mezunu, ev hanımı veya çalışamayan kadınların üstlendiği görülmektedir. Çalışmanın yatağa bağımlı ve birden fazla kronik hastalığ üzerinde yapıldığı göz önünde bulunduğunda, alanda eğitimli bir hemşirenin bile baş etmekte zorlanabileceği durumlarla eğitim düzeyi düşük bakım veren ve hastanın baş başa kaldığ1 gerçeği ortaya çıkmaktadır. Katılımciların sosyodemografik verileri incelendiğinde bakım verenlerin çoğunluğunun sosyokültürel ve sosyoekonomik gelişmişlik düzeyinin düşük olduğu sonucuna varılabilir(Tablo.1) . $\mathrm{Bu}$ duruma bakım verdiği hastanın ihtiyaçları nedeniyle artan ekonomik giderler de eklendiğinde tüm aile olumsuz etkilenebilir. $\mathrm{Bu}$ nedenle evde sağlık hizmeti veren sağlık çalışanları Aile ve Sosyal Politika Bakanlığı'nın sunduğu ekonomik destekler ve Sosyal Güvenlik Kurumu (SGK) geri ödemeleri kapsamı konusunda eğitim ve danışmanlık sağlayarak hem bakım veren hem de bakım alan desteklenmelidir.

Çalışmada bakım veren ortalama 1440 gündür (yaklaşı iki yıl) hastasına bakmaktadır. Uzun süre yatağa bağıml hastasına bakım vermek, bakım yükünü ve ekonomik yükü artırabilir. Bu durum bakım veren aile bireyinde ve bakım alanda fiziksel ve psikolojik olumsuz sonuçları tetikleyebilir. Evde sağlık hizmet sunucularının sadece hasta için değil, bu noktada tüm aile bireylerini etkileyecek eğitim ve danışmanlık hizmeti vermesi önemlidir.

Çalışmada bakım alanların yaş medyanı kontrol grubunda 72, müdahale grubunda 75 olarak gözlenmiştir. Bakım alanların çoğunluğunun yaşlı bireylerden oluştuğunu göstermektedir. $\mathrm{Bu}$ durum hem literatür hem de evde sağlık istatistiklerinde bildirilen hasta profili ile uyumludur .6,16,19,29 Çalışmaya katılan hastaların \%52,9'u ilkokul mezunu, 
Tablo 4. Bakım alan hastaların demografik bulguları

\begin{tabular}{|c|c|c|c|c|c|c|c|}
\hline & \multicolumn{2}{|c|}{ Kontrol } & \multicolumn{2}{|c|}{ Çalışma } & \multirow{2}{*}{ Toplam (n) } & \multirow{2}{*}{$\%$} & \multirow{2}{*}{$\mathbf{p}^{*}$} \\
\hline & (n) & $\%$ & (n) & $\%$ & & & \\
\hline \multicolumn{8}{|l|}{ Cinsiyeti } \\
\hline Kadın & 66 & 51,2 & 60 & 51,3 & 126 & 51,2 & \multirow{3}{*}{0,985} \\
\hline Erkek & 63 & 48,8 & 57 & 48,8 & 120 & 48,8 & \\
\hline Toplam & 129 & 100 & 117 & 100 & 246 & 100 & \\
\hline \multicolumn{8}{|l|}{ Sosyal Güvencesi } \\
\hline Var & 111 & 86 & 102 & 87,9 & 213 & 86,9 & \multirow{3}{*}{0,662} \\
\hline Yok & 18 & 14 & 14 & 12,1 & 32 & 13,1 & \\
\hline Toplam** & 129 & 100 & 116 & 100 & 245 & 100 & \\
\hline \multicolumn{8}{|l|}{ Öğrenim Durumu } \\
\hline $\begin{array}{l}\text { Okur-yazar } \\
\text { değil }\end{array}$ & 37 & 28,7 & 34 & 29,1 & 71 & 28,9 & \multirow{5}{*}{0,930} \\
\hline Okur-yazar & 13 & 10,1 & 10 & 8,5 & 23 & 9,3 & \\
\hline İlkokul & 56 & 43,4 & 49 & 41,9 & 105 & 42,7 & \\
\hline $\begin{array}{l}\text { Ortaokul ve } \\
\text { üzeri }\end{array}$ & 23 & 17,9 & 24 & 20,5 & 47 & 19,1 & \\
\hline Toplam & 129 & 100 & 117 & 100 & 246 & 100 & \\
\hline \multicolumn{8}{|l|}{ Medeni Durumu } \\
\hline Evli & 67 & 51,9 & 61 & 52,1 & 128 & 52 & \multirow{5}{*}{0,896} \\
\hline Hiç evlenmemiş & 18 & 14 & 20 & 17,1 & 38 & 15,4 & \\
\hline Eşi ölmüş & 38 & 29,5 & 31 & 26,5 & 69 & 28 & \\
\hline Boşanmış & 6 & 4,7 & 5 & 4,3 & 11 & 4,5 & \\
\hline Toplam & 129 & 100 & 117 & 100 & 246 & 100 & \\
\hline \multicolumn{8}{|l|}{$\begin{array}{l}\text { Kronik Hastalık } \\
\text { Sayısı }\end{array}$} \\
\hline $1-2$ & 22 & 17,2 & 25 & 21,4 & 47 & 19,2 & \multirow{3}{*}{0,407} \\
\hline 3 ve üzeri & 106 & 82,8 & 92 & 78,6 & 198 & 80,8 & \\
\hline Toplam** & 128 & 100 & 117 & 100 & 245 & 100 & \\
\hline \multicolumn{8}{|l|}{$\begin{array}{l}\text { Hasta Bireyin } \\
\text { Hastalık Süresi (yıl) }\end{array}$} \\
\hline $0-2$ & 24 & 18,8 & 28 & 23,9 & 52 & 21,2 & \multirow{4}{*}{0,536} \\
\hline $3-4$ & 23 & 18 & 17 & 14,5 & 40 & 16,3 & \\
\hline 4 ve üzeri & 81 & 63,3 & 72 & 61,5 & 153 & 62,4 & \\
\hline Toplam** & 128 & 100 & 117 & 100 & 245 & 100 & \\
\hline \multicolumn{8}{|l|}{ Alışkanlıkları } \\
\hline Sigara & 30 & 23,3 & 27 & 23,1 & 57 & 23,2 & \multirow{3}{*}{0,974} \\
\hline $\begin{array}{l}\text { Alışkanlığ yok } \\
\text { (sigara, alkol, } \\
\text { madde } \\
\text { kullanımı) }\end{array}$ & 99 & 76,7 & 90 & 76,9 & 189 & 76,8 & \\
\hline Toplam & 129 & 100 & 117 & 100 & 246 & 100 & \\
\hline \multicolumn{8}{|l|}{$\begin{array}{l}\text { Bakım Alanlarda } \\
\text { Bası Ülseri }\end{array}$} \\
\hline Yok & 111 & 86 & 98 & 83,8 & 209 & 85 & \multirow{3}{*}{0,616} \\
\hline Var & 18 & 14 & 19 & 16,2 & 37 & 15 & \\
\hline Toplam & 129 & 100 & 117 & 100 & 246 & 100 & \\
\hline
\end{tabular}

** Bir kayıp veri * ki-kare analizi, 
Tablo 5. Müdahale ve kontrol grubundaki hastaların Geriatrik Depresyon Ölçeği ve Braden Skalası (Bası Ülseri) sonuçlarının karşılaştırılması

\begin{tabular}{|c|c|c|c|c|c|c|c|c|c|c|}
\hline & \multicolumn{4}{|c|}{ Ön-Test } & \multicolumn{4}{|c|}{ Son -Test } & \multicolumn{2}{|c|}{ Ön-Test/Son-Test } \\
\hline $\begin{array}{l}\text { Geriatrik } \\
\text { Depresyon } \\
\text { Ölçeği }\end{array}$ & $\mathbf{n} *$ & Ortanca & $\begin{array}{c}25 .-75 . \\
\text { persentil }\end{array}$ & $\mathbf{p}^{*}$ & n* & Ortanca & $\begin{array}{c}25 .-75 . \\
\text { persentil }\end{array}$ & $\mathbf{p}^{*}$ & $\begin{array}{c}\mathbf{P}^{* *} \\
\text { (Grup) }\end{array}$ & $\begin{array}{c}\mathbf{P}^{* *} \\
\text { (Toplam) }\end{array}$ \\
\hline Kontrol & 65 & 19 & $13-22$ & \multirow{2}{*}{0,845} & 45 & 17 & $11-20$ & \multirow{2}{*}{0,471} & 0,131 & \multirow{2}{*}{0,004} \\
\hline Müdahale & 54 & 18 & $14-22$ & & 49 & 15 & $12-19$ & & $\mathbf{0 , 0 1 1}$ & \\
\hline \multicolumn{11}{|c|}{ Bası Yarası Risk Tanılama Toplam Puan } \\
\hline Kontrol & 106 & 15 & $12-17$ & \multirow{2}{*}{0,696} & 106 & 14 & $10,7-17$ & \multirow{2}{*}{0,790} & 0,494 & \multirow[t]{2}{*}{0,046} \\
\hline Müdahale & 115 & 15 & $12-18$ & & 97 & 14 & $10-17$ & & $\mathbf{0 , 0 3 3}$ & \\
\hline
\end{tabular}

*Çalışmaya katılan bireylerden yaşlılık, demans, gibi nörolojik nedenlerle etkin iletişim kurulamadığından veri toplamada güçlükle karşılaşılmıştır. Bu sebeple veri toplanamayan sorular (boş bırakılan) işlenemediğinden " $n$ " toplamları farklıdır. Ön- test sırasinda kontrol gurubunun \%59,44'üne, müdahale gurubunun \%60,68'ne, son-test sirasında ise kontrol gurubunun \%49,61'i ile, müdahale gurubunun \%45,56'sıyla iletişim kurulabilmiş olup sonuçlar tabloda verilmiştir. *Mann-Whitney $\mathrm{U}$ testi, $\mathrm{t}$ testi,

**Wilcoxon Signed Ranks Testi

Tablo 6. Aile üyeleri tarafından verilen bakımı değerlendirme envanteri, zarit bakıcı yükü ve bakım verme bilgi düzeyi değerlendirme sonuçlarının karşılaştırması

\begin{tabular}{|c|c|c|c|c|c|c|c|c|c|c|}
\hline & \multicolumn{4}{|c|}{ Ön-Test } & \multicolumn{4}{|c|}{ Son-Test } & \multicolumn{2}{|c|}{$\begin{array}{c}\text { Son-Test/ } \\
\text { Ön-Test }\end{array}$} \\
\hline & (n) & Ortanca & $\begin{array}{c}25 .-75 . \\
\text { persentil }\end{array}$ & $\mathbf{p}^{*}$ & (n) & Ortanca & $\begin{array}{c}25 .-75 . \\
\text { persentil }\end{array}$ & $\mathbf{p}^{*}$ & $\begin{array}{c}\mathbf{P}^{* *} \\
\text { Grup } \\
\text { içi }\end{array}$ & $\begin{array}{c}\mathbf{p}^{* *} \\
\text { Toplam }\end{array}$ \\
\hline \multicolumn{11}{|c|}{ 1) Bakım Verenin Bakım Verdiği Bireyle İlgili Yeterliliği } \\
\hline Kontrol & 129 & 29 & $25-33$ & \multirow{2}{*}{0,265} & 129 & 30 & $27-35$ & \multirow{2}{*}{$<0,001$} & 0,010 & \multirow[t]{2}{*}{$<0,001$} \\
\hline Müdahale & 117 & 28 & $23-32$ & & 117 & 34 & $30-35$ & & $<0,001$ & \\
\hline \multicolumn{11}{|c|}{ 2) Bakım Vermede Yaşanan Güçlükler } \\
\hline Kontrol & 129 & 15 & $10-21,5$ & \multirow{2}{*}{0,491} & 129 & 14 & $10-18$ & \multirow{2}{*}{$\mathbf{0 , 0 4 9}$} & 0,191 & \multirow[t]{2}{*}{$<0,001$} \\
\hline Müdahale & 117 & 16 & $11-21$ & & 117 & 11,5 & $8-18$ & & $<0,001$ & \\
\hline \multicolumn{11}{|c|}{ 3) Bakım Verme Kaynakları } \\
\hline Kontrol & 129 & 20 & $16-21$ & \multirow{2}{*}{0,301} & 129 & 20 & $16-21$ & \multirow{2}{*}{$<0,001$} & 1,00 & \multirow[t]{2}{*}{$<0,001$} \\
\hline Müdahale & 117 & 21 & $17-21$ & & 117 & 21 & $20-21$ & & $<0,001$ & \\
\hline \multicolumn{11}{|c|}{ 4) Bakım Verenin Kendisinden Beklentileri } \\
\hline Kontrol & 129 & 10 & $10-11$ & \multirow{2}{*}{0,853} & 129 & 11 & $10-13$ & \multirow{2}{*}{$<0,001$} & $<0,001$ & \multirow[t]{2}{*}{$<0,001$} \\
\hline Müdahale & 117 & 10 & $10-11$ & & 117 & 15 & $12-15$ & & $<0,001$ & \\
\hline \multicolumn{11}{|c|}{ Zarit Bakıcı Yükü̈**** } \\
\hline Kontrol & 113 & 42 & $23-52$ & \multirow{2}{*}{0,437} & 107 & 38 & $25-51$ & \multirow{2}{*}{0,011} & 0,043 & \multirow[t]{2}{*}{$<0,001$} \\
\hline Müdahale & 107 & 40 & $24-49$ & & 98 & 31 & $17-44$ & & $<0,001$ & \\
\hline \multicolumn{11}{|c|}{ Yatağa Bağımlı Hasta Bakımı Bilgi Düzeyi Değerlendirme Testi ${ }^{* * * *}$} \\
\hline Kontrol & 129 & 18 & $13-24$ & \multirow{2}{*}{0,191} & 107 & 30 & $23-33$ & \multirow{2}{*}{0,033} & $<0,001$ & \multirow{2}{*}{$<0,001$} \\
\hline Müdahale & 117 & 21 & $13-24$ & & 98 & 31 & $29-33$ & & $<0,001$ & \\
\hline
\end{tabular}

*Mann-Whitney U testi, $\mathrm{t}$ testi,

** Wilcoxon Signed Ranks Testi

****Zarit Bakıcı Yükü Anketleri ve Yatağa Bağımlı Hasta Bakımı Bilgi Düzeyi Değerlendirme Testinde boş bırakılan veya atlanan soruları olan anketler dışlandığından örneklem sayısı azalmıştır. 
\%28,9'u okur yazar değildir, üç ve üzeri kronik hastalığı olanların oranı \%80,2'dir. Bu sonuca dayanarak, sosyokültürel olarak düşük eğitim seviyesindeki yaşlı ve kronik hastalıklara sahip yatağa bağımlı bireylerin hak ihlalleri, yaşam kalitesi vb. açısından da önemle üzerinde durulmas1, korunmas1, hassas guruplar olarak çok boyutlu olarak ele alınması gereken bir konu olduğunu düşündürmektedir. Bu durum ülkemizde artan yaşlı nüfus ve bağlı olarak artan kronik hastalıklarla birlikte düşünüldüğünde yaşlı bireylerin evde bakımı konusunun her açıdan önemini gündeme getirmektedir.

Proje kapsamında müdahale grubunda daha fazla olmak üzere yatağa bağımlı hastaların toplam \%15'inde bası yarası bulunmaktaydı (Tablo:4). Çalışma sonucunda bası yarası risk düzeyinin müdahale grubu lehine farklı olduğu bulunmuştur. Müdahale grubunda Braden Skalası ortanca değeri ve persentillerinde düşüş gözlenmiştir (Tablo:5). Yatağa bağımlı hastalarda yetersiz hijyen, yetersiz beslenme ve immobilizasyon gibi nedenlerle bası yarası oluşabilmektedir. Bası yarasının hasta için acı verici bir durum olduğu ve enfeksiyon, diyabet gibi durumlarda tedavisinin güç olabileceği bilinmektedir. Hem evde sağlık ekibi hem de bakım verenlere yapılan eğitimlerde basınç ülserinin önlenmesi konusunda önemle vurgu yapılmış olmasının sonuçları etkilemiş olduğu düşünülmektedir.

Müdahale grubunda bulunan yatağa bağımlı hastalarda, geriatrik depresyon ortanca değerinin 18 'den 15 'e düştüğü ve depresyon belirtilerinin azaldığı bulunmuştur(Tablo.5) $(p<0.05)$. Çalışmaya katılan yatağa bağımlı hastalar içinde kas hastalıkları, nörolojik hastalıklar vb. bulunduğundan etkin iletişim kurulamaması nedeniyle, ön ve son testlerde değerlendirmeye alınan hasta sayısı azalmıştır. Ön- test sirasinda kontrol gurubunun \%59,4'ü, müdahale gurubunun \%60,7'si, son-test sirasinda ise kontrol gurubunun \%49,6's1, müdahale gurubunun \%45.6's1 ile iletişim kurulabilmiş olup sonuçlar Tablo 5 'de verilmiştir. Bununla birlikte bulgular, bakım verenlere yapılan eğitimlerin hastanın depresif belirtilerini azaltma yönünde etki etmiş olabileceğine ilişkin ipuçları vermektedir. Yapılan girişimler sonrası bakım verenlerin yeterliliği, kendisinden beklentileri, bakım verme kaynakları, bakım verme bilgisi ve bakım verme yükü algılarındaki olumlu değişimlerin bu sonucu olumlu etkilemiş olabileceği düşünülmektedir (Tablo. 6).
Çalışmada yatağa bağımlı hastaların bakım vericilerine yapılan eğitimlerin bakım verenlerin bakımla ilgili bilgi düzeyinin artmasında, bakım verme yeterliliğini arttırmada, bakım vermede yaşanan güçlükleri azaltmada, bakım verme kaynaklarını artırmada ve bakıcı yükünü azaltmada etkili olduğu bulunmuştur ve literatürde bu konuda yapılan çalışmaları desteklediği belirlenmiştir. 16,30,31,20,32 Cingil ve Gözüm (2016) tarafından yapılan sistematik derlemede bakım verilenlere yönelik yapılan eğitim ve destek girişimlerinin hasta ve bakım veren sonuçlarını olumlu etkilediği raporlanmıştır. ${ }^{16}$

Evde bakım hizmetinden sorumlu olan aile bireylerinin sağlık personeli tarafından eğitimi ve psikososyal açıdan destek sağlanması hem etkin bir iş birliğini sağlayarak hasta açısından önem taşımakta hem de bakım veren kişilerin kendi sağlıklarını korumalarına katkı sağlama açısından önem taşımaktadır. $\mathrm{Bu}$ anlamda verilecek eğitimler ve yapılması gereken müdahaleler, eğitimi alacak kişilerin özelliklerine göre farklılık gösterebilmekle birlikte, bu anlamdaki herhangi bir müdahalenin varlığı bile bakıcıların yaptıkları işten tatmin olmalarını ve verdikleri hizmet konusunda iç görü geliştirmelerini sağlamaktadır. ${ }^{33}$

Demir ve arkadaşlarının yaptığ 1 sistematik incelemede; değerlendirmeye alınan 20 çalışmanın 15'inde aile bakım verenlerini hasta bakımına ilişkin geliştirmeyi amaçlayarak yapılan girişimlerin ölçülen tüm sonuçlarda müdahale grubu lehine anlamlı sonuçlandığ belirlenmiştir. Özetle, yapılan eğitimsel girişimler bakım verenlerin yeterliliğini, iyilik halini, yaşam kalitesini geliştirmiş, hastanın hastaneye yeniden yatışı, ailelerin bakım yükü algısı, depresyon ve stresi azaltmıştır. ${ }^{34}$ Bakım veren aile bireylerine yönelik yapılan girişimlerin etkinliğinin incelendiği bir diğer sistematik derleme yazısında, ölçülen sonuçlar, kontrol grubuyla kıyaslandığında müdahale grubunda daha olumlu gelişme göstermiştir. Yirmi üç deneysel çalışmanın alındığı bu çalışmada, bakım veren aile bireylerine yönelik girişim tipleri incelendiğinde; psikososyal destek, eğitim, var olan hizmetlerin organizasyonunu, internet kursu, hemşirelik bakımı, uğraşı terapisi hem eğitim hem de psikososyal destek, psikososyal destek ve yoga, eğitim-psikososyal destek-hizmet organizasyonunu bir arada uygulayan çalışmalar tespit edilmiştir. Bu çalışmalardan 21 'inde yapilan girişim müdahale grubu lehine anlamlı bulunmuştur. ${ }^{16}$ 
Konuya ilişkin çalışmalar incelendiğinde evde bakım hizmetlerinde bakıcı olarak yer alan aile bireylerinin sağlık profesyonelleri ile daha iyi bir iletişim içinde olmalarının gerekli olduğu, bu tür desteklerin aileye yakın kişiler veya diğer aile bireyleri tarafından sağlanmasının da yararlı olabileceği vurgulanmaktadır. Ancak, bu konuda ihtiyaç duydukları psikososyal destek ile bilgi desteğinin yeterince karşılanmadığı dikkati çekmektedir . 35,36,37

Eğitimin etkinliğini hasta ve bakım veren açısından değerlendiren çok sayıda çalışma hatta yukarda bahsedilen sistematik derleme ve meta-analiz çalışmaları yapılmıştır. Bu çalışma kapsamındaki tüm eğitimlerde Asubel'in sunuş yolu ile öğretim stratejisi kullanılmıştır. Aynı yöntem ve metodolojiyi birlikte kullanan benzer bir çalışma bulunamamış olup, benzer çalışmaların yapılması durumunda bilimsel çıktıların artmasına ve evde sağlık hizmetlerinin gelişimine katkıda bulunacaktır. 16,33,34,38,39,40

\section{Araştırmada Yaşanan Güçlükler ve Sinırlılıklar}

Yatağa bağımlı hastası olan bakım verenlerin eğitime tam katılımını sağlayabilmek için üç belediyenin evde bakım birimleri, bakım verenlerin evinden alınmasına ve hastaların bakılmasına kendi belediye sınırları içinde destek oldu. Belediyelerin ve Halk Sağlığ1 Müdürlüğü Evde Sağlık Birimleri ile iki hastanenin evde sağlık ekipleri eğitim verirken bakım desteği sağladı. Ancak, tüm kurumların imkanları bu eğitim için seferber edildiği, her türlü kolaylık sağlandığı halde, hastasının kötüleşmesi gibi sebeplerle eğitime devamsızlıklar görüldü. Eğitimin tamamlanması için telafi eğitim programı yapıldı. Ön ve son testlerde kullanılan veri toplama araçlarındaki soru sayısı fazla olduğu için veriler ön ve son test sırasında ikişer ziyaret ile topland.

Eğitim veren ve verileri toplayan 21 evde sağlık çalışanı arasında eğitim ve veri toplama standardizasyonu sağlamak amaciyla değerlendirme toplantıları yapılmıştır. Bakım verenlerin eğitimi iki hastanenin konferans salonlarında aynı içerikle verilerek girişim standardizasyonu sağlanmıştır.

Vefat, başka yere taşınma ve eğitime katılmadıkları için örneklemden çıkarma nedeniyle hasta ve bakım veren kayb1 yaşandiğından son testlerde örnek büyüklüğünde azalma olmuştur. Yatağa bağımlı hastaların büyük çoğunluğu ile yeterli iletişim kurulamadığından Geriatrik Depresyon Ölçeği için örnek büyüklüğü azalmıştır. Çalışma sonuçlarının bu sınırlılıklar göz önünde bulundurularak değerlendirilmesi önerilmektedir.

\section{SONUÇ VE ÖNERÍLER}

$\mathrm{Bu}$ çalışmada evde sağlık hizmetlerinden hizmet alan yatağa bağımlı hastaların bakım vericilerine sunuş yoluyla yapılan eğitimin bakım verme yeterliliğini artırmada etkili olduğu, bakıcı yükünü anlamlı olarak azalttığı, bakım verme bilgi düzeyini arttırdığ bulunmuştur. Sunuş yoluyla verilen eğitimin hastaların iyilik halini arttırdığı, depresyon düzeyini azalttığı, bası ülseri risklerini anlamlı olarak azalttığı bulunmuştur. Çalışmamızın sonuçlarına göre aşağıdaki öneriler sunulmuştur.

Toplumsal kaynakların kullanımında aile bakım vericilerine danışmanlık ve destek sağlanmalı, aile bakım vericilerine yatağa bağımlı hasta bakımına ilişkin öğretim stratejilerine dayandırılarak hazırlanmış eğitimler yapılmalı ve bu eğitimlerin yaygınlaştırılması sağlanmalıdır. Bakım veren aile bireylerinin bilgiye ulaşımını kolaylaştıracak uzaktan eğitim modelleri, açık erişim kaynakları ve eğitim modülleri gibi yöntemler geliştirilmeli ve etkinliği ölçülmelidir.

\section{TEŞEKKÜR}

Bu çalışma, TÜBİTAK tarafından 2014-2016 tarihleri arasinda 213S075 numaralı proje kapsamında desteklenmiştir. Projemizi destekleyen TÜBİTAK'a teşekkür ederiz.

Projemiz kapsamında bakım veren aile bireylerine yönelik hazırlanan web sayfasının içindeki eğitim videolarının hazırlanmasında ve eğitimlerde destek olan; Prof. Dr. Nevzat YALÇIN, Prof. Dr. Hasan Şenol ÇOŞKUN, Prof. Dr. Emine EFE, Prof. Dr. Fusun TORAMAN, Doç. Dr. Fatma CEBECİ, Doç. Dr. Hicran BEKTAŞ, Doç. Dr. Sema SEZGIN GÖKSU, Yrd. Doç. Dr. Fatma ARIKAN, Uzm. Dr. Arzu Didem YALÇIN, Uzm. Dr. Kasım GÖKTAŞ, Uzm. Dr. Banu BEKÖZ, Uzman Dr. Asim USLU, Uzm. Dr. Nuray AYPER ÖNGEN, Uzm. Dr Raif. Umut AYOĞLU, Uzm. Dr Çağrı GÜNAYDIN, Dt. Tijen ARIBAŞ, Dt.Mustafa ULUKAYA, Sosyal Hizmet Uzmanı Refik AKTEN, Sebahat BALCI ve Sibel ATABAY, Diyetisyen Selçuk YURTTAŞ ve Özen UYSAL, Fizyoterapist Sedat BAYRAK ve 
Buket ÇELIK, Hemşire Zehra Esin GENCER, Hemşire Aysel TEKELİ, Hemşire Yasemin KONDAK, Hemşire Yeşim ÇEVIK, Hemşire Ferda ERDEM, Hemşire Keziban ÖZCAN, Psikolog İncifer LEYLEK, Hemşire Güliz GÜZELBABA, Sağlık Memuru Serkan BEŞEVLİ Prof.Dr.Zeynep CANLI ÖZER, Yrd.Doç.Dr. Hakan Gülkesen, Öğr.Gör. Nurcan KIRCA, Arş.Gör. Yasemin DEMIR AVCI'ya, Arş.Gör. Ayşegül ILGAZ'a ve projenin çıktısı olan web sayfasının sürdürülebilirliği için http://antalyaesh.saglik.gov.tr/ ismiyle alan adı sağlayan Antalya İl Sağlık Müdürlüğü'ne ve hosting desteği sağlayan Sağlık Bakanlığımıza teşekkür ederiz.

$\mathrm{Bu}$ çalışma, TÜBİTAK tarafindan 20142016 Tarihleri arasinda 213S075 numaralı proje kapsamında desteklenmiş ve 4. Uluslararası Evde Sağlık ve Sosyal Hizmetleri Kongresinde sözlü bildiri olarak sunulmuştur.

\section{KAYNAKLAR}

1. Türkiye İstatistik Kurumu haber bülteni; 2013.

http://www.tuik.gov.tr/PreHaberBultenleri .do?id=13466, Erişim Tarihi:13.02.2019

2. Beşer A, Bahar Z. Evde Bakım, Akademi Basin ve Yayıncilık, 2017, S:12.

ISBN:978-605-82106-0-8.

3. Saraç M. İstanbul Büyükşehir Belediyesi Sağlık Daire Başkanlığı Kurumsal Bakım Hizmetleri, Uluslararası Palyatif Bakım Kongresi Kitapçı̆̆1,2017, S:39.

4. Karabağ H. "Evde sağlik bakım hizmetlerinin Türkiye'de uygulanabilirliğine ilişkin hekimlerin görüşleri ve kardiyoloji hastaları için hastane destekli evde bakım hizmetleri model önerisi" Yüksek Lisans Tezi, Gazi Üniversitesi, Sosyal Bilimler Enstitüsü, İşletme Anabilim Dalı, 2007, S:36. https://www.ulusaltezmerkezi.net/searchw psolr/?search $=\mathrm{Evde}+\mathrm{sa} \% \mathrm{C} 4 \% 9 \mathrm{Fl} \% \mathrm{C} 4 \% \mathrm{~B}$ $1 \mathrm{k}+\mathrm{bak} \% \mathrm{C} 4 \% \mathrm{~B} 1 \mathrm{~m}+$ hizmetlerinin+T\%C3 $\%$ BCrkiye $\%$ E2\%80\%99de+uygulanabilirl i\%C4\%9Fine+ili\%C5\%9Fkin+hekimlerin $+\mathrm{g} \% \mathrm{C} 3 \% \mathrm{~B} 6 \mathrm{r} \% \mathrm{C} 3 \% \mathrm{BC} \% \mathrm{C} 5 \% 9$ Fleri+ve+ kardiyoloji+hastalar\%C4\% $1+\mathrm{B} \% \mathrm{C} 3 \% \mathrm{~A} 7$ in+hastane+destekli+evde+bak\%C4\% B1 m+hizmetleri+model $+\% \mathrm{C} 3 \%$ B6nerisi Erişim Tarihi:13.02.2019

5. Antalya Kamu Hastaneleri Birliği Evde Sağllk Hizmetleri El Rehberi, Versiyon 2,
Antalya Kamu Hastaneleri Birliği, 2015;S:3-4.

6. Keklik K. Evde Sağlık Hizmetlerinde Mevcut Durum, 4. Uluslararası Evde Sağlık ve Sosyal Hizmetler Kongresi, Kongre Kitab1, 03-05 Aralık 2015, S;23. https://docs.wixstatic.com/ugd/9f5914_55 a136722ed348e49100ecfa5b9df067.pdf. Erişim Tarihi:13.02.2019

7. Antalya İl Sağlık Müdürlüğü TİSIMM Verileri, İl Sağlık Müdürlüğü Evde Sağlık Biriminden 30.09.2017 tarihli yazı ile temin edilmiştir; 2017.

8. Karahan A, Güven S. "Yaşlılıkta Evde Bakım", Geriatri, 2002; 5(4): 155-9.

9. Feldman F.H,Waliser M.N., Gould D.A, Levine C. "When the care givers needs care: the plight of vulnerable caregivers", American journal of public health, 2002, 92(3): 409.

10. Güven S, Hazer O. "Ülkemizde evde bakım sistemlerinin aile ve yaşlılık açısından gereği, önemi ve bu konuda ev ekonomistlerinin yeri", I. Ulusal Evde Bakım Kongresi Kitabı, İstanbul, I. Ulusal Evde Bakım Kongresi Kitabı, İstanbul, 1998;155-159.

11. Aksayan S, Cimete G. "Kronik hastalıklı bireylerin evde bakım gereksinimleri olanakları ve tercihleri", I.Ulusal Evde Bakım Kongresi Kitabı, İstanbul, 1998;150-155.

12. Dramalı A, Demir F, Yavuz M. "Evde kronik hastaya bakım veren hasta yakınlarının karşılaştıkları sorunlar”. I. Ulusal Evde Bakım Kongresi Kitabı, İstanbul;1998;160-163

13. Altun İ. "Hasta yakınlarının bakım verme rolünde zorlanma durumları”, I.Ulusal Evde Bakım Kongresi Kitabı, İstanbul;1998.170-175.

14. Cuijpers $P$, "Depressive disorders in caregivers of dementia patients: a systematic review". Aging Mental Health,2005;9(4): 325-30.

15. Pinquart M, Sörensen S. "Differences between care givers and noncaregivers in psychological healt hand physical health: A meta-analysis. Psychol Aging, 2003;18(2):250-67. 
16. Cingil D, Gözüm S. "Hastasına evde bakım veren aile bakım vericilerinin güçlendirilmesi: Sistematik derleme". Türkiye Klinikleri Halk Sağlığı Hemşireliği Özel Dergisi (E-Dergi), Sağlık ve Sosyal Boyutlarıyla Evde Bakım Özel Sayıs1, 2016;2(3):60-72.

17. Sunay D ve ark. CONSORT 2010 Raporu: Randomize Paralel Grup Çalışmalarının Raporlanmasında Güncellenmiş

Kilavuzlar, Euras J FamMed 2013; 2(1):110.

18. CONSORT web sayfas1, http://www.consort-statement.org/ , Erişim tarihi:09.04.2019.

19. Cingil D. "Bağımlı yaşlısına bakım veren aile üyelerine sunuş yolu ile verilen eğitimin bakım verme yeterliliği ve yaşlı bakımı bilgi düzeyine etkisi", Doktora Tezi, Atatürk Üniversitesi, Sağlık Bilimleri Enstitüsü, Erzurum; 2013,S;4445.

20. Cingil D, Gözüm S, Bodur S. "Bağımlı yaşlısına bakım veren aile üyelerine sunuş yolu ile verilen eğitimin bakım verme yeterliliği ve yaşlı bakımı bilgi düzeyine etkisi" Anadolu Hemşirelik ve Sağlık Bilimleri Dergisi, 2015;18:4.

21. İnci H.F. Bakım verme yükü ölçeğinin Türkçeye uyarlanması, geçerlilik ve güvenilirliği, Yüksek Lisans Tezi, Pamukkale Üniversitesi Sağlık Bilimleri Enstitüsü, Denizli;2006,S;36-41.

22. Cingil D, Gözüm S. Yaşlı Bireyler İçin "Aile üyeleri tarafından verilen bakımı değerlendirme envanteri'nin Geçerlilik ve Güvenilirliği Dokuz Eylül Üniversitesi Hemşirelik Yüksekokulu Elektronik Dergisi, 2008; 1 (1), 5-18.

23. Oğuz S, Olgun N. Braden Ölçeği ile hastaların risklerinin belirlenmesi ve planlı hemşirelik bakımının bası yaralarının önlenmesindeki etkinliğinin saptanması. Hemşirelik Forumu Dergisi,1998; (3)1, 131-135.

24. Pınar R, Oğuz S. Norton ve Braden Bası Yarası Değerlendirme Ölçeklerinin yatağa bağımlı aynı hasta grubunda güvenirlik ve geçerliliklerinin sınanması. VI. Ulusal Hemşirelik Kongre Kitab1;1998; 172-175.
25. Yesavage J. A, Brink T.L, Rose T.L, et al. "Development and validation of a geriatric depression screening scale: a preliminary report". J Psychiatr Res 1983;17;(1):3749.

26. Ertan T. "Geriatrik depresyon ölçeği ile kendini değerlendirme depresyon ölçeğinin 60 yaş üzeri türk popülasyonunda geçerlilik -güvenirlik incelemesi", Uzmanlık Tezi, İstanbul Üniversitesi, Cerrahpaşa Tıp Fakültesi Psikiyatri Anabilim Dalı, İstanbul;1996,S;42-45.

27. Ertan T, Eker E, Şar V. “Geriatrik depresyon ölçeğinin Türk yaşlı nüfusunda geçerlilik ve güvenilirliği. Noropsikiyatri Arşivi, 1997; 34(1):62-71.R.G.Sayıs1: 25751.

28. Sağlık Bilimleri Üniversitesi Antalya Eğitim ve Araştırma Hastanesi Evde Sağlık Web sayfası, https://antalyaesh.saglik.gov.tr/ Erişim Tarihi:05.04.2019

29. Çatak B, Kılınç A, Badıllıoğlu O, Sütlü S, Sofuoğlu A, Aslan D. "Burdur'da evde sağlık hizmeti alan yaşıı hastaların profili ve evde verilen sağlık hizmetleri”, Türkiye Halk Sağlığı Dergisi, 2012; 10 (1).

30. Nicolaides-Bouman A, Van Rossum E, Habets H, Kempen G.I, Knipschild P. "Home visiting programme for older people with health problems: processe valuation". Journal of Advanced Nursing; 2007;58(5): 425-35.

31. Temizer H, Gözüm S. "Impactof nursing care initiatives on the knowledge level homecare to stroke patients", HEALTHMED, vol.6, pp, 2012;.26812688.

32. Bodur S, Cingil D. Bağımlı yaşlıların aile içi bakıcılarının bakımla ilgili tutumları ve eğitimle ilişkisi. Selçuk Üniversitesi Tıp Dergisi,2006; 22 (4): 149-57.

33. Holm M, Carlander I, Fürst C.J, Wengström Y, Arested K, Öhlen J, Henrikkson A. Delivering and participating in a pscho education a intervention for family caregivers during palliative homecare: a qualitative study from perspectives of health professionals 
and family caregivers. BMC Palliative Care, 2015;14:16.

34. Avc1 YD, Gözüm S, Özer Z. İnmeli hastaların ailelerinin, bakım verme yeterliliğini geliştirmek için yapılan girişimler: Sistematik Derleme. TJFM\&PC,2016;10(3):164-174.

DOI:10.21763/tjfmpc.46799, http://dergipark.gov.tr/download/articlefile/222582

Erişim Tarihi;14.02..2019.

35. Candy B, Jones L, Drake R, Leurent B, King M. "Interventions for supporting in formal caregivers of patients in the terminal phase of a disease". Cochrane Database SystRev;2011;6:CD007617.

36. Ventura A.D, Burney S, Brooker J, Fletcher J, Ricciardelli L. "Home-based palliative care: A systematic review of the self-reportedunmet needs of patients and carers". Palliat Med;2014;28(5):391-402.
37. Shiba K, Kondo N, Kondo K. "Informal and formal social support and caregiver burden. The AGES Caregiversurvey". J Epidemiol; 2016, JE20150263.

38. Berg-Weger B, Tebb SS.Conservations with researchers about family caregiving: trends and future directions. Generations 2003-2004; 27(4): 9-16.

39. Magnusson L, Hanson E. "Supporting frail older people and their family carers at home using information and communication technology: costanalysis". Journal of Advanced Nursing;2005; 51(6):645-57.

40. Çakıcı D, Alver B, Ada Ş. Anlamlı öğrenmenin öğretimde kullanımı. Kazım Karabekir Eğitim Fakültesi Dergisi, Sayı 13, 2006;71-80. 